\title{
Productivity of temperate broad-leaved forest stands differing in tree species diversity
}

\author{
Mascha JACOB $^{1 *}$, Christoph LeUSCHNER ${ }^{1}$, Frank M. THOMAS ${ }^{2}$ \\ ${ }^{1}$ Albrecht-von-Haller-Institute for Plant Sciences, Department of Plant Ecology, Georg-August-Universität Göttingen, Untere Karspüle 2, \\ 37073 Göttingen, Germany \\ ${ }^{2}$ Geobotany, Faculty of Geography and Geosciences, University of Trier, Behringstr. 21, 54296 Trier, Germany
}

(Received 9 March 2009; accepted 22 September 2009)

\author{
Keywords: \\ Central Europe / \\ allometry / \\ leaf area index / \\ seasonal growth pattern / \\ temperate forest
}

\author{
Mots-clés : \\ Europe centrale / \\ allométrie / \\ indice de surface foliaire / \\ modèle de croissance saisonnière / \\ forêt tempérée
}

\begin{abstract}
- Understanding the effects of tree species diversity on biomass and production of forests is fundamental for carbon sequestration strategies, particularly in the perspective of the current climate change. However, the diversity-productivity relationship in old-growth forests is not well understood. - We quantified biomass and above-ground production in nine forest stands with increasing tree species diversity from monocultures of beech to stands consisting of up to five deciduous tree species (Fagus sylvatica, Fraxinus excelsior, Tilia spp., Carpinus betulus, Acer spp.) to examine (a) if mixed stands are more productive than monospecific stands, (b) how tree species differ in the productivity of stem wood, leaves and fruits, and (c) if beech productivity increases with tree diversity due to lower intraspecific competition and complementary resource use.

- Total above-ground biomass and wood production decreased with increasing tree species diversity. In Fagus and Fraxinus, the basal area-related wood productivity exceeded those of the co-occurring tree species, while Tilia had the highest leaf productivity. Fagus trees showed no elevated production per basal area in the mixed stands.

- We found no evidence of complementary resource use associated with biomass production. We conclude that above-ground productivity of old-growth temperate deciduous forests depend more on tree species-specific traits than on tree diversity itself.
\end{abstract}

Résumé - Productivité de peuplements de forêt tempérée feuillue présentant différents niveaux de diversité.

- Comprendre les effets de la diversité des espèces d'arbres sur la biomasse et la production des forêts est fondamental pour les stratégies de piégeage du carbone, en particulier dans la perspective des changements climatiques actuels. Cependant, dans les vieilles forêts la relation diversité-productivité n'est pas bien comprise.

- Nous avons quantifié la biomasse et la production hors-sol de neuf peuplements forestiers à diversité croissante, allant de monocultures de hêtre jusqu'à des peuplements constitués d'un maximum de cinq espèces d'arbres à feuilles caduques (Fagus sylvatica, Fraxinus excelsior, Tilia spp., Carpinus betulus, Acer spp.) afin d'examiner (a) si les peuplements mélangés sont plus productifs que les peuplements monospécifiques, (b) comment diverses espèces d'arbre diffèrent pour la productivité du bois de la tige, des feuilles et des fruits, et (c) si la productivité du hêtre augmente avec la diversité en relation avec une baisse de la compétition intra-spécifique et une complémentarité dans l'utilisation de ressources.

- La biomasse aérienne totale et la production de bois ont diminué quand la diversité des espèces d'arbres augmentait. Pour Fagus et Fraxinus, la productivité en bois estimée d'après la surface terrière dépassait celle des autres espèces, tandis que Tilia avait la plus forte productivité en feuilles. Dans les peuplements mixtes, les hêtres ne présentaient pas de gain de productivité ramenée à la surface terrière.

- Nous n'avons trouvé aucune preuve d'une complémentarité de l'utilisation de ressources liées à la production de biomasse. Nous concluons que la productivité des parties aériennes des vieux peuplements feuillus tempérés, dépend davantage de traits spécifiques des différentes espèces que de la diversité en espèces.

\footnotetext{
* Corresponding author: mjacob@gwdg.de
} 


\section{INTRODUCTION}

The role of plant species diversity for ecosystem processes such as biomass production, sequestration of nutrients, and the fluxes of energy and matter belongs to the most challenging topics of current ecological research, especially on the background of the current climate change (e.g. Fornara and Tilman, 2008; Yachi and Loreau, 2007). Whilst, during the past two decades, extensive studies have been conducted on the effects of plant species diversity on biomass production in grasslands (e.g. Hooper et al., 2005; Spehn et al., 2005), such studies have been performed to a much smaller extent in forest ecosystems. In theory, increased biomass production in stands that are more diverse in plant species or plant functional groups may be a consequence of positive interactions among the species or may result from complementarity in resource use, e.g., increased depletion of light, water or nutrients by coexisting plant species (e.g. Hooper and Vitousek, 1997). In forest ecosystems, most studies comparing speciespoor and species-rich stands contrasted plots with one and two tree species (cf. Cannell et al., 1992). Hitherto, the number of studies on the effects of tree species diversity on tree biomass production is too small to allow general conclusions on systematic productivity differences between monospecific tree stands and stands with more than one tree species (Rothe and Binkley, 2001; Rothe et al., 2002).

Due to the Ice Ages, the tree species diversity of CentralEuropean forests, which - without anthropogenic interference - would be dominated by the European beech (Fagus sylvatica L.) except for very dry, wet or acidic sites and the upper montane regions, is much lower than in the temperate zones of other continents. Anthropogenic use during the past two millennia, including the establishment of fastgrowing monospecific coniferous stands outside their natural habitats, has lowered tree species diversity even more. Currently, Central-European forestry is conducting a conversion of monospecific into mixed stands in part of the forested area (e.g. BMVEL, 2001). However, the consequences of this conversion for productivity, biotic interactions and the fluxes of energy and matter as well as for ecosystem goods and services used by man are insufficiently known. Therefore, a long-term study on the role of biodiversity for biogeochemical cycles and biotic interactions has been established in the Hainich National Park (Thuringia, Central Germany), which is richer in tree species (up to 14 deciduous tree species per hectare) than most other forest ecosystems in Central Europe. In the context of the Hainich Tree Diversity Matrix Project, mature monospecific stands built by European beech are being compared to mature stands consisting of three or five deciduous tree species (Guckland et al., 2009; Leuschner et al., 2009). One of the foci of the study is to analyze the relationship between tree species diversity and above-ground biomass production, which is not fully understood. The results of field studies (Cannell et al., 1992; Vilà et al., 2003) and of a meta-analysis (Augusto et al., 2002) failed to yield general relationships between tree species number and production of above-ground tree biomass (Enquist and Niklas, 2001). However, a possibility not investigated so far is that the productivity of mixed stands is higher than that of pure beech stands because different tree species in mixed stands differ in their seasonal growth dynamics. In this case, complementarity would be due to temporal rather than spatial partitioning of essential resources such as light, water and nutrients, and one would expect that the productivity of European beech is higher in mixed stands than in pure beech stands. In addition, the productivity of the beech in mixed stands may be higher in pure beech stands due to the alleviation of intraspecific competition (cf. Pretzsch and Schütze, 2009). We tested these hypotheses by analyzing stem increment and biomass production of leaves and fruits, and by relating productivity to tree species diversity. This comparative study in the oldgrowth stands of the Hainich Tree Diversity Matrix is viewed as a complementary research approach to recently initiated experiments with planted stands differing in tree species diversity (e.g. Scherer-Lorenzen et al., 2005).

\section{MATERIALS AND METHODS}

\subsection{Study area and sampling design}

We conducted the study in the Hainich National Park, Thuringia, Central Germany, in old-growth deciduous forest stands that differ in tree species diversity. All research sites are situated at an elevation of about $350 \mathrm{~m}$ a.s.l. near the village of Weberstedt $\left(51^{\circ} 06^{\prime} \mathrm{N}\right.$, $\left.10^{\circ} 31^{\prime} \mathrm{E}\right)$. The mean annual temperature at the Weberstedt meteorological station is $7.5^{\circ} \mathrm{C}$ and the mean annual precipitation is $670 \mathrm{~mm}$. Soils are Luvisols with a loess cover of at least $60 \mathrm{~cm}$ and stagnic properties, and are underlain by limestone (Guckland et al., 2009). The studied stands have been managed only with stem-wise extraction for the past four decades and have developed a near-natural structure. A small-scale mosaic of forest ownership with different forest management systems including coppice with standards and selective tree cutting has resulted in the existence of tree species-poor and tree species-rich stands in close neighborhood (Leuschner et al., 2009).

In April 2005, forest stands differing in tree taxa diversity were selected in the north-eastern part of the national park and grouped into three diversity levels (DL): (i) four forest stands of European beech Fagus sylvatica L. contributing with $85 \%$ to $100 \%$ to the total tree basal area (DL 1); (ii) four stands mainly consisting of beech, lime Tilia cordata Mill. and T. platyphyllos Scop. and ash Fraxinus excelsior L. (DL 2); and (iii) four stands with five dominant tree taxa (beech, lime, ash, hornbeam Carpinus betulus L. and maple Acer pseudoplatanus L. and A. platanoides L.) (DL 3). The dominant trees had an average age of 85-148 years (in 2006) according to wood core analysis conducted by Schmidt et al. (2009). The plot size within a forest stand was $50 \mathrm{~m} \times 50 \mathrm{~m}$. At each DL, three plots were fenced to exclude wild boar and game, and one plot remained unfenced. All forest stands were located within a radius of about $4 \mathrm{~km}$, and were comparable with respect to slope and climatic conditions. The fenced plots also exhibited the same soil physical conditions. Their stand characteristics are presented in Table I.

\subsection{Determination of biomass and productivity}

In summer 2005, the diameter at breast height (dbh) was recorded using measurement tapes in all trees of the 12 forest stands with a diameter at breast height ( $\mathrm{dbh}$ ) exceeding $7 \mathrm{~cm}$. For all calculations, 
Table I. Study sites description (means $\pm 1 \mathrm{SE}$ of data from three plots). Different letters indicate significant differences between the three diversity levels; $p<0.05$.

\begin{tabular}{|c|c|c|c|}
\hline Site structure & DL 1 & DL 2 & DL 3 \\
\hline Shannon Index H' (No. of stems) & $0.3 \pm 0.1 \mathrm{c}$ & $1.1 \pm 0.1 \mathrm{~b}$ & $1.6 \pm 0.1$ \\
\hline Mean number of tree genera per plot & $3 \pm 0.9 \mathrm{~b}$ & $5 \pm 0.7 \mathrm{ab}$ & $6 \pm 0.7 \mathrm{a}$ \\
\hline Basal area $\left(\mathrm{m}^{2} \mathrm{ha}^{-1}\right)$ & $41 \pm 2.8 \mathrm{a}$ & $39 \pm 3.7 \mathrm{a}$ & $36 \pm 2.4 \mathrm{a}$ \\
\hline Stem density $(>7 \mathrm{~cm} \mathrm{dbh})\left(\mathrm{ha}^{-1}\right)$ & $291 \pm 69 a$ & $581 \pm 101 \mathrm{a}$ & $397 \pm 39 a$ \\
\hline Mean age of canopy trees $(\mathrm{yr})$ & $148 \pm 25 \mathrm{a}$ & $85 \pm 6.5 \mathrm{~b}$ & $100 \pm 8.4 \mathrm{ab}$ \\
\hline Mean tree height $(\mathrm{m})^{*}$ & $35.7 \pm 1.5 \mathrm{a}$ & $28.7 \pm 0.6 b$ & $26.7 \pm 0.4 \mathrm{~b}$ \\
\hline Height/diamenter (HD value) $\left(\mathrm{m} \mathrm{m}^{-2}\right)^{*}$ & $73.5 \pm 2.5 \mathrm{a}$ & $84.6 \pm 4.5 \mathrm{a}$ & $75.1 \pm 3.2 \mathrm{a}$ \\
\hline Leaf area index $\left(\mathrm{m}^{2} \mathrm{~m}^{-2}\right)$ & $6.4 \pm 0.3 \mathrm{a}$ & $6.9 \pm 0.3 \mathrm{a}$ & $7.1 \pm 0.5 \mathrm{a}$ \\
\hline Mean crown area $\left(\mathrm{m}^{2}\right)^{*}$ & $55.9 \pm 10 \mathrm{a}$ & $36.7 \pm 6.9 \mathrm{a}$ & $51.2 \pm 1.9 \mathrm{a}$ \\
\hline Mean crown diameter $(\mathrm{m})^{*}$ & $8.0 \pm 0.8 \mathrm{a}$ & $6.5 \pm 0.6 \mathrm{a}$ & $7.5 \pm 0.2 \mathrm{a}$ \\
\hline Height of crown base $(\mathrm{m})^{*}$ & $18.5 \pm 0.6 \mathrm{a}$ & $14.7 \pm 0.9 \mathrm{~b}$ & $13.5 \pm 0.2 b$ \\
\hline Total canopy cover $(\%)$ & $85.5 \pm 1.5 b$ & $90.8 \pm 0.6 \mathrm{a}$ & $89.3 \pm 1.5 \mathrm{a}$ \\
\hline Fagus (\% of total canopy cover) & $96.1 \pm 1.9 \mathrm{a}$ & $67.1 \pm 3.5 b$ & $21.4 \pm 13 \mathrm{c}$ \\
\hline Tilia (\% of total canopy cover) & $0.8 \pm 0.8 \mathrm{~b}$ & $13.1 \pm 5.3 \mathrm{ab}$ & $40.3 \pm 11 \mathrm{a}$ \\
\hline Fraxinus ( $\%$ of total canopy cover) & $0.5 \pm 0.5 \mathrm{a}$ & $14.2 \pm 3.9 \mathrm{a}$ & $10.7 \pm 4.3 \mathrm{a}$ \\
\hline Acer (\% of total canopy cover) & $0.9 \pm 0.4 b$ & $4.5 \pm 1.0 \mathrm{~b}$ & $8.5 \pm 1.3 \mathrm{a}$ \\
\hline Carpinus (\% of total canopy cover) & $0.0 \pm 0.0 \mathrm{~b}$ & $0.0 \pm 0.0 \mathrm{~b}$ & $14.7 \pm 5.2 \mathrm{a}$ \\
\hline Others (\% of total canopy cover) & $1.7 \pm 1.7 \mathrm{a}$ & $1.0 \pm 1.0 \mathrm{a}$ & $4.5 \pm 2.9 \mathrm{a}$ \\
\hline
\end{tabular}

${ }^{*}$ Dominant and co-dominant trees, class 1 and 2 after Kraft (1884).

however, the values of the nine fenced plots were used. In winter 2005/2006, tree height was measured using a Vertex sonic clinometer and transponder (Haglöf Sweden AB, Långsele, Sweden), and crown area was determined by 8-point canopy projection with a sighting tube equipped with a $45^{\circ}$ mirror (constructed in the Department of Remote Sensing, University of Göttingen, Germany). Mean tree height was calculated from dominant and co-dominant trees according to class 1 and 2 Kraft (1884) to minimize e.g. the influence of self-thinning processes or the regeneration differences of the stands. Species-specific allometric biomass equations were used to calculate the above-ground woody biomass of the trees. Biomass of Fagus and Carpinus was computed using linear equations with natural logarithmic transformation based on dbh and tree height (Wirth et al., 2004):

$$
\ln (y)=a+b \cdot \ln (d b h)+c \cdot \ln (d b h)^{2}+d \cdot \ln (h)+e \cdot \ln (h)^{2} ;
$$

where $y=$ biomass (kg dry mass); $a=-3.4719, b=1.90119$, $c=0, d=0.98218, e=0$ for stems; $a=-0.92263, b=2.68122$, $c=0.09993, d=-1.91638, e=0.14018$ for branches and twigs; $d b h=$ diameter at breast height $(\mathrm{cm}), h=$ tree height $(\mathrm{m})$. Total aboveground woody biomass was calculated by summing up the biomasses of stem, branches and twigs.

The woody biomass of T. cordata, A. pseudoplatanus, and F. excelsior was determined according to Bunce (1968) (see also Zianis et al., 2005):

$$
\ln (A B W)=a+b \cdot \ln (d b h)
$$

where $a=-2.6788$ and $b=2.4542$ in the Tilia species; $a=-2.7606$ and $b=2.5189$ in the Acer species; $a=-2.4598$ and $b=2.4882$ for F. excelsior $A B W=$ above-ground woody biomass (kg dry mass), $d b h=$ diameter at breast height $(\mathrm{cm})$. For all forest stands, the soil surface area-related woody biomass (in $\mathrm{Mg} \mathrm{ha}^{-1}$ ) was calculated.

From August 2005 to December 2007, stem diameter increment was measured at a height of $130 \mathrm{~cm}$ in all trees with $d b h \geq 40 \mathrm{~cm}$ using increment measurement tapes (D1 permanent measurement tape, UP, Cottbus, Germany). Trees with a smaller dbh were assigned to two stem diameter classes ( 7 to $<20 \mathrm{~cm}$ and 20 to $<40 \mathrm{~cm}$ ), and subsamples of these classes were considered for growth increment measurements according to their share in total stem number. Annual wood production at the plot level (in $\mathrm{Mg} \mathrm{ha}^{-1} \mathrm{y}^{-1}$ ) was calculated from the relative annual increment of wood biomass of all tree species present. Two plots (DL 1c and DL 3a) were partly destroyed by storms in summer 2006 and winter 2007/2008. These plots were excluded from the increment measurements and in these cases, wood productivity was calculated from the unfenced plots DL $1 \mathrm{~d}$ and DL $3 \mathrm{~d}$.

In the nine fenced forest stands, we determined the production of leaf and fruit biomass using litter traps. In each forest stand, 15 litter collectors (aperture: $0.29 \mathrm{~m}^{2}$ ) were arranged at a minimum distance of $2 \mathrm{~m}$ along randomly positioned $30-\mathrm{m}$ transects. Water was allowed to drain from the collectors through $8-\mathrm{mm}$ holes drilled through the bottom. Leaf litter was sampled every two to three weeks during September to December 2005-2007 and, additionally, once in spring and once in late summer of 2006. All samples were separated into leaves, fruits, flowers and twigs. Leaves and fruits were assigned to the different tree species, oven-dried at $70{ }^{\circ} \mathrm{C}$ for $48 \mathrm{~h}$, and weighed. Tilia cordata and T. platyphyllos were considered as one taxon as they hybridize and could not be separated into species. Soil surface area-related annual leaf production was calculated as the sum of the collected mass of leaf litter divided by the surface area of the collector. The leaves were scanned and the surface area was calculated using WinFolia software (Regent Instruments, Quebec, Canada). LAI was obtained by multiplying stand leaf biomass per species with the species-specific average of specific leaf area (SLA).

\subsection{Statistical analyses}

Statistical data analysis and regression analyses were conducted using the software packages $R$, version 2.8.1 ( $R$ Development Core Team, Vienna, Austria) and SigmaPlot, version 10.0 (Systat Software Inc., San Jose, USA). To examine differences among the diversity levels (DL 1-3) between the study years and between tree species within 
one diversity level, we performed an analysis of variance (ANOVA) followed by the Tukey test for all pairwise comparisons of means when assumptions of normality and homogeneity of variances were met ( $p<0.05$; Shapiro-Wilk test, Levene test). In the case of nonnormally distributed data, a Kruskal-Wallis single factor analysis of variance followed by non-parametric Mann-Whitney two sample Utests was applied ( $p<0.05$ in all analyses).

Simple regression analyses were used to analyze the relationship between tree species diversity (Shannon Index $\mathrm{H}^{\prime}$ ) on the one hand, and total above-ground biomass, LAI and variables of productivity, on the other. We conducted a multiple regression analysis after zero mean - unit variance standardisation of the explanatory variables Shannon Index $\mathrm{H}^{\prime}$ and stand age to consider the effects of these factors on the productivity of leaves, fruits, wood and total above-ground productivity (sum of leaves, fruits and wood) simultaneously. Autocorrelation between the explanatory variables was moderate $\left(R^{2}=\right.$ $0.45)$ and the variance inflation factor of the models was considerably low $(V I F=2.046)$. The fit of the model was checked graphically on normal distribution and heteroscedasticity of the model residuals. Akaike's Information Criterion (AIC) of each model was given.

Within a given diversity level, we performed a Kruskal-Wallis single factor analysis and non-parametric Mann-Whitney two sample $U$-tests to examine differences between tree species in the cumulative relative diameter growth. Trees with no basal area increment in the specific year were excluded.

\section{RESULTS}

\subsection{Stand structure}

The forest stands of the three diversity levels (DL) did not differ significantly in basal area, stem density, height:diameter ratio (HD value), LAI, mean crown area and mean crown diameter (Tab. I). Significant differences between the diversity levels existed for tree age, tree height and height of crown base, which were higher in the monospecific forest stands, and for total canopy cover. The absolute differences between the three diversity levels were rather small, however. Thus, the forest stands were comparable with regards to fundamental characteristics of their stand and canopy structure. The differences in the tree species composition among the three DL are reflected by a significantly decreasing fraction of Fagus and increasing fractions of Tilia, Acer and C. betulus in the total canopy cover, and by a concomitant increase from DL 1 to DL 3 in the tree genus-related Shannon index, as calculated for tree species and based on stem numbers (Tab. I).

\subsection{Above-ground biomass and productivity}

The total above-ground tree biomass of the nine forest stands ranged from 200 to $480 \mathrm{Mg} \mathrm{ha}^{-1}$ (Fig. 1). The highest figure was determined in an almost pure Fagus stand. The above-ground biomass decreased significantly with increasing Shannon diversity $\mathrm{H}^{\prime}$ of the tree layer.

The production of leaves and fruits did not correlate with the tree diversity (Fig. 2). In 2006, which was a mast year in

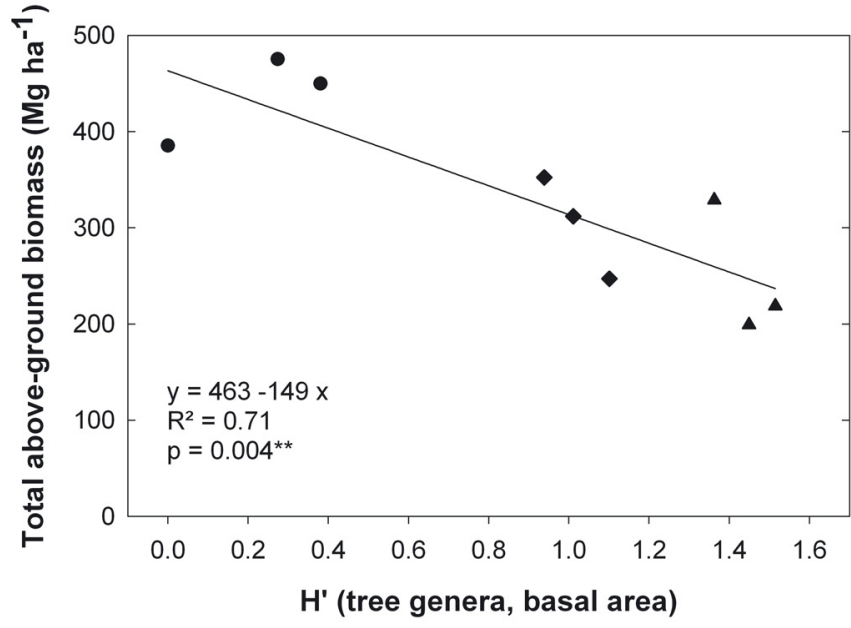

Figure 1. Relationship between total above-ground biomass (stem and branch wood, leaves, fruits) and the Shannon Index $\mathrm{H}^{\prime}$ of the tree layer (calculated from the basal area of all tree genera). $N=3$ plots per diversity level. • DL 1; DL 2; $\Delta$ DL 3.

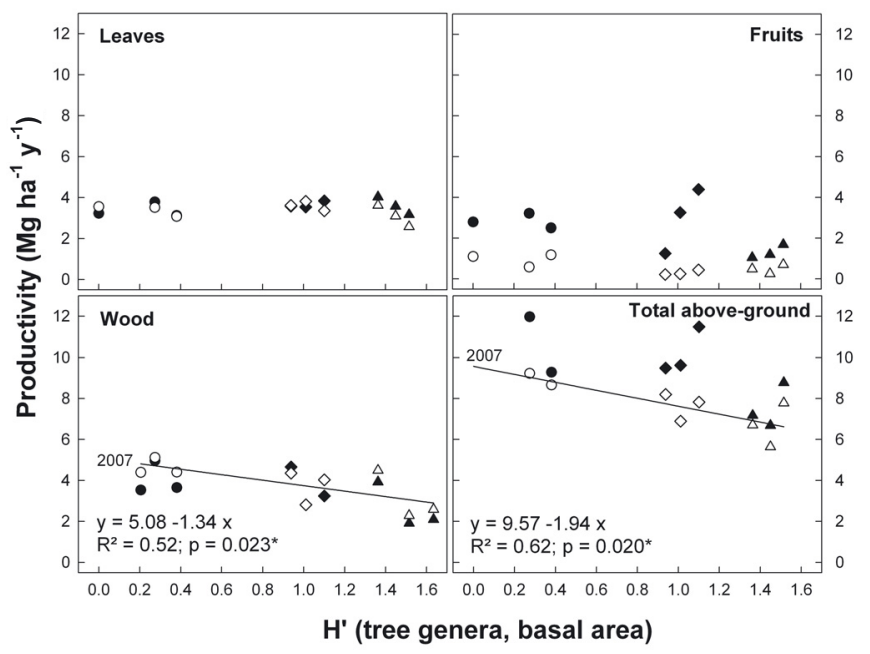

Figure 2. Productivity of leaves, fruits, wood and total above-ground biomass plotted against the Shannon Index $\mathrm{H}^{\prime}$ of the tree layer (calculated from the basal area of all tree genera). • DL 1; DL 2; $\triangle$ DL 3. Data of 2006, closed symbols; data of 2007, open symbols.

beech, the mass of produced fruits reached almost $3 \mathrm{Mg} \mathrm{ha}^{-1}$ in the DL 1 and DL 2 forest stands and, thus, was nearly as high as leaf production.

The production of wood and the total above-ground biomass was highest in the pure Fagus stands and decreased with increasing tree species diversity $\mathrm{H}^{\prime}$ (significant in 2007). The results of the regression analysis showed a higher influence of $\mathrm{H}^{\prime}$ than of stand age or the interaction of both factors on productivity measures (Tab. II). The coefficients can be directly compared because the explanatory variables were standardised to zero mean and unit variance. 
Table II. Regression models for the productivity of leaves, fruits, wood and total above-ground biomass obtained by linear multiple regression with two explanatory variables (Shannon Index $\mathrm{H}^{\prime}$ and stand age). AIC, Akaike's Information Criterion.

\begin{tabular}{|c|c|c|c|c|c|}
\hline Response variable & Explanatory variable & Coefficient & $t$ & $\bar{p}$ & Model statistics \\
\hline \multicolumn{6}{|l|}{ Leaf productivity } \\
\hline & Stand age & -0.207 & -0.794 & 0.463 & AIC 11.097 \\
\hline & $\mathrm{H}^{\prime}$ & -0.160 & -0.914 & 0.403 & $F(3,5 \mathrm{DF})=0.4446$ \\
\hline & Stand age: $\mathrm{H}^{\prime}$ & -0.007 & -0.034 & 0.974 & $p=0.7316$ \\
\hline \multicolumn{6}{|l|}{ Fruit productivity } \\
\hline & Stand age & -0.334 & -0.713 & 0.508 & AIC 21.662 \\
\hline & $\mathrm{H}^{\prime}$ & -0.488 & -1.551 & 0.182 & $F(3,5 \mathrm{DF})=1.082$ \\
\hline & Stand age: $\mathrm{H}^{\prime}$ & -0.170 & -0.490 & 0.645 & $p=0.4365$ \\
\hline \multicolumn{6}{|l|}{ Wood productivity } \\
\hline & Stand age & -0.411 & -1.085 & 0.328 & AIC 24.955 \\
\hline & $\mathrm{H}^{\prime}$ & -1.038 & -2.976 & $0.031 *$ & $F(3,5 \mathrm{DF})=3.143$ \\
\hline & Stand age: $\mathrm{H}^{\prime}$ & 0.202 & 0.429 & 0.686 & $p=0.1248$ \\
\hline \multicolumn{6}{|c|}{ Total above-ground productivity } \\
\hline & Stand age & -0.489 & -1.310 & 0.247 & AIC 24.672 \\
\hline & $\mathrm{H}^{\prime}$ & -1.580 & -4.599 & $0.006 * *$ & $F(3,5 \mathrm{DF})=7.402$ \\
\hline & Stand age: $\mathrm{H}^{\prime}$ & 0.448 & 0.965 & 0.379 & $p=0.027 *$ \\
\hline
\end{tabular}

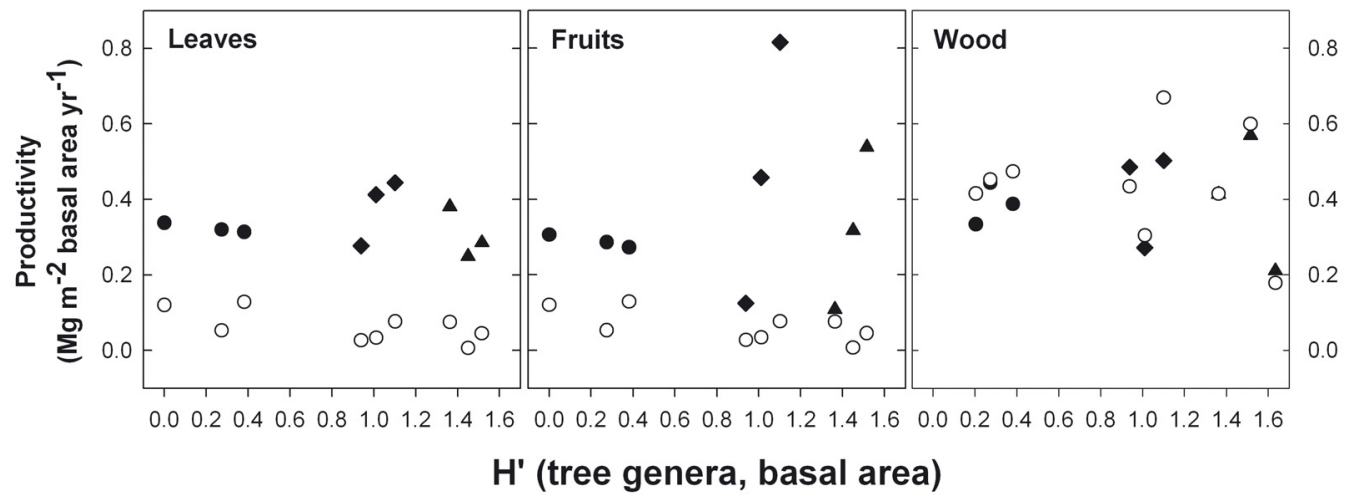

Figure 3. Relationship between the basal area-related productivity of leaves, fruits and wood in Fagus sylvatica and the Shannon Index $\mathrm{H}^{\prime}$ of the tree layer (calculated from the basal area of all tree genera). • DL 1; DL 2; $\Delta$ DL 3. Data of 2006, closed symbols; data of 2007, open symbols.

When relating the production of wood, leaves and fruits to the tree basal area instead of the plot area, a similar picture of species-specific and DL-specific production patterns appeared (Tab. $S 1^{1}$ available online only) as in the plot-area related data (Tab. $\mathrm{S} 2^{1}$ ).

The calculation of the LAI allowed a year-wise comparison among the DL. Mean LAI values ranged between 6.4 and $7.1 \mathrm{~m}^{2} \mathrm{~m}^{-2}$ without exhibiting significant differences among the DL or between the years (Tab. I).

\subsection{Species-specific productivity}

The basal area-related production of wood, leaves and fruits of Fagus was independent from the tree species diversity $\mathrm{H}^{\prime}$ (Fig. 3). Regarding only the dominant and co-dominant $\mathrm{Fa}$ gus trees, the differences in the relative basal area increment

\footnotetext{
${ }^{1}$ Supplementary materials Tables S1 and S2 are available at www.afsjournal.org.
}

were not significant among the diversity levels (Tab. III). In the other species, the diversity level had no significant influence on the relative basal area increment as well. The highest rates of relative increment were found in Fraxinus, and the lowest, in Acer.

Tilia and Fraxinus occur in the mixed-species forest stands of DL 2 and DL 3. Related to the basal area, Tilia produced significantly more basal area-related leaf biomass, while wood productivity of ash was significantly higher compared to the other species (Fig. 4). In the mast year of 2006, only Carpinus reached values of fruit production that were similar to those of Fagus (Tab. S2).

\subsection{Seasonal course of biomass production}

The seasonal course of the basal area-related cumulative stem increment ("cumulative relative diameter increment", $\mathrm{CDI}$ ) demonstrates different growth dynamics of the individual species during each vegetation period (Fig. 5). In 2006, 
Table III. Relative basal-area increment of dominant and co-dominant trees (in $\% \mathrm{y}^{-1}$ ) (means \pm 1 SE of data from 3 plots). Different lowercase letters indicate significant differences between the three diversity levels, capital letters indicate significant differences between different years.

\begin{tabular}{|c|c|c|c|c|c|c|}
\hline & \multicolumn{2}{|c|}{ DL 1} & \multicolumn{2}{|c|}{ DL 2} & \multicolumn{2}{|c|}{ DL3 } \\
\hline & 2006 & 2007 & 2006 & 2007 & 2006 & 2007 \\
\hline Fagus sylvatica & $\begin{array}{c}0.90 \pm 0.11 \\
\text { a A }\end{array}$ & $\begin{array}{c}1.08 \pm 0.07 \\
\text { a A }\end{array}$ & $\begin{array}{c}1.25 \pm 0.23 \\
\text { a A }\end{array}$ & $\begin{array}{c}1.47 \pm 0.24 \\
\text { a A }\end{array}$ & $\begin{array}{c}1.01 \pm 0.23 \\
\text { a A }\end{array}$ & $\begin{array}{c}1.11 \pm 0.18 \\
\text { a A }\end{array}$ \\
\hline Fraxinus excelsior & & & $\begin{array}{c}1.92 \pm 0.24 \\
\text { a A }\end{array}$ & $\begin{array}{c}1.67 \pm 0.06 \\
\text { a A }\end{array}$ & $\begin{array}{c}1.78 \pm 0.33 \\
\text { a A }\end{array}$ & $\begin{array}{c}2.04 \pm 0.20 \\
\text { a A }\end{array}$ \\
\hline Tilia sp. & & & $\begin{array}{c}0.69 \pm 0.24 \\
\text { a A }\end{array}$ & $\begin{array}{c}1.12 \pm 0.12 \\
\text { a A }\end{array}$ & $\begin{array}{c}0.80 \pm 0.09 \\
\text { a A }\end{array}$ & $\begin{array}{c}1.43 \pm 0.15 \\
\text { a B }\end{array}$ \\
\hline Acer sp. & & & & & $\begin{array}{c}0.57 \pm 0.17 \\
\mathrm{~A}\end{array}$ & $\begin{array}{c}0.76 \pm 0.25 \\
\mathrm{~A}\end{array}$ \\
\hline Carpinus betulus & & & & & $\begin{array}{c}0.89 \pm 0.22 \\
\mathrm{~A}\end{array}$ & $\begin{array}{c}0.92 \pm 0.33 \\
\mathrm{~A}\end{array}$ \\
\hline
\end{tabular}

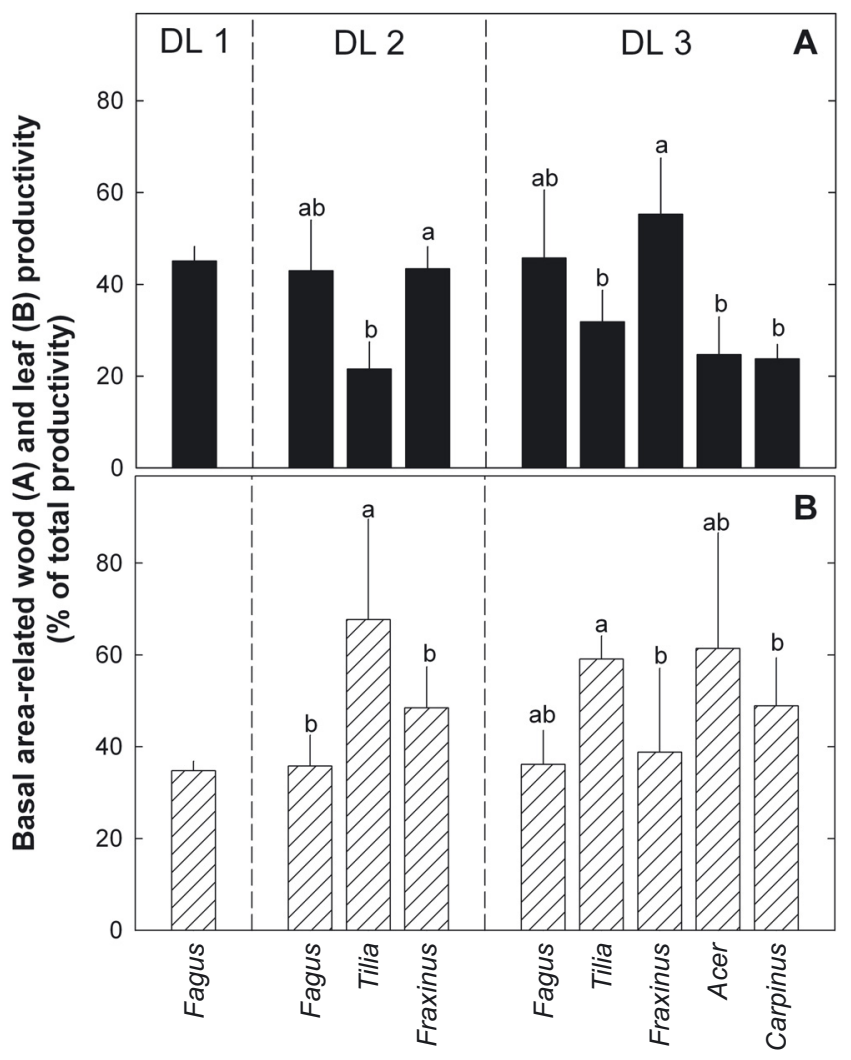

Figure 4. Basal area-related wood and leaf productivity in \% of total above-ground productivity (mean values of 2006 and 2007 plus 1 standard error; $N=3$ ). Significant differences between species at a given diversity level are indicated with small Latin letters.

when cool and humid weather predominated until the beginning of June, the trees exhibited sigmoid increment curves with the largest increment between June and August. One exception is Fraxinus showing a saturation curve with maximum growth rates already occurring between April and June. In the year 2007, which was characterized by an exceptionally warm and dry April, we detected near-linear increments from April to June or August in all tree species.
In Fagus, CDI was significantly lower from April to June than in Fraxinus (Fig. 5). From April to June 2006, CDI was significantly lower in Acer than in all other investigated tree genera. In that year, Acer, Carpinus, Tilia and Fagus displayed a steep increase in CDI from June to August. The rapid diameter increase in Tilia partly was caused by a decrease in diameter from April to June 2006. In 2007, we found very similar growth patterns in Fagus and Tilia as well as in Carpinus and Acer.

\section{DISCUSSION}

In nine old-growth forest stands with increasing tree species diversity of broad-leaved Central-European tree species, we found no increase in above-ground productivity with increasing tree species diversity. Rather, there was a decline of wood and total above-ground productivity with increasing diversity of tree genera. This finding is in contrast to the results of several other studies on forests. Whilst model simulations predict that the productivity of mixed stands will generally be intermediate between that of the respective monospecies stands (Bartelink, 2000), field studies revealed that, compared to monospecies stands, the productivity of mixed stands can decrease or increase by up to $30 \%$, depending on the specific physiology and growth potential of the species (Pretzsch, 2005). In Southern Germany, mixed stands of Fagus sylvatica and Picea abies produced up to $59 \%$ more above-ground biomass than adjacent pure stands (Pretzsch and Schütze, 2009). The authors explained this finding by a reduction in intraspecific competition among Fagus trees (which, for beech, is more severe than interspecific competition with spruce), and by facilitation brought about by Fagus to the benefit of Picea through an improvement of nutrient supply by deeper soil exploitation, higher nutrient turnover, and activation of the humus layer.

In contrast, wood production did not differ significantly among monospecies and mixed forests dominated by Pinus sylvestris or P. halepensis in Southeastern Spain when environmental factors such as climate, bedrock types, and radiation were included in the analysis (Vilà et al., 2003). However, 

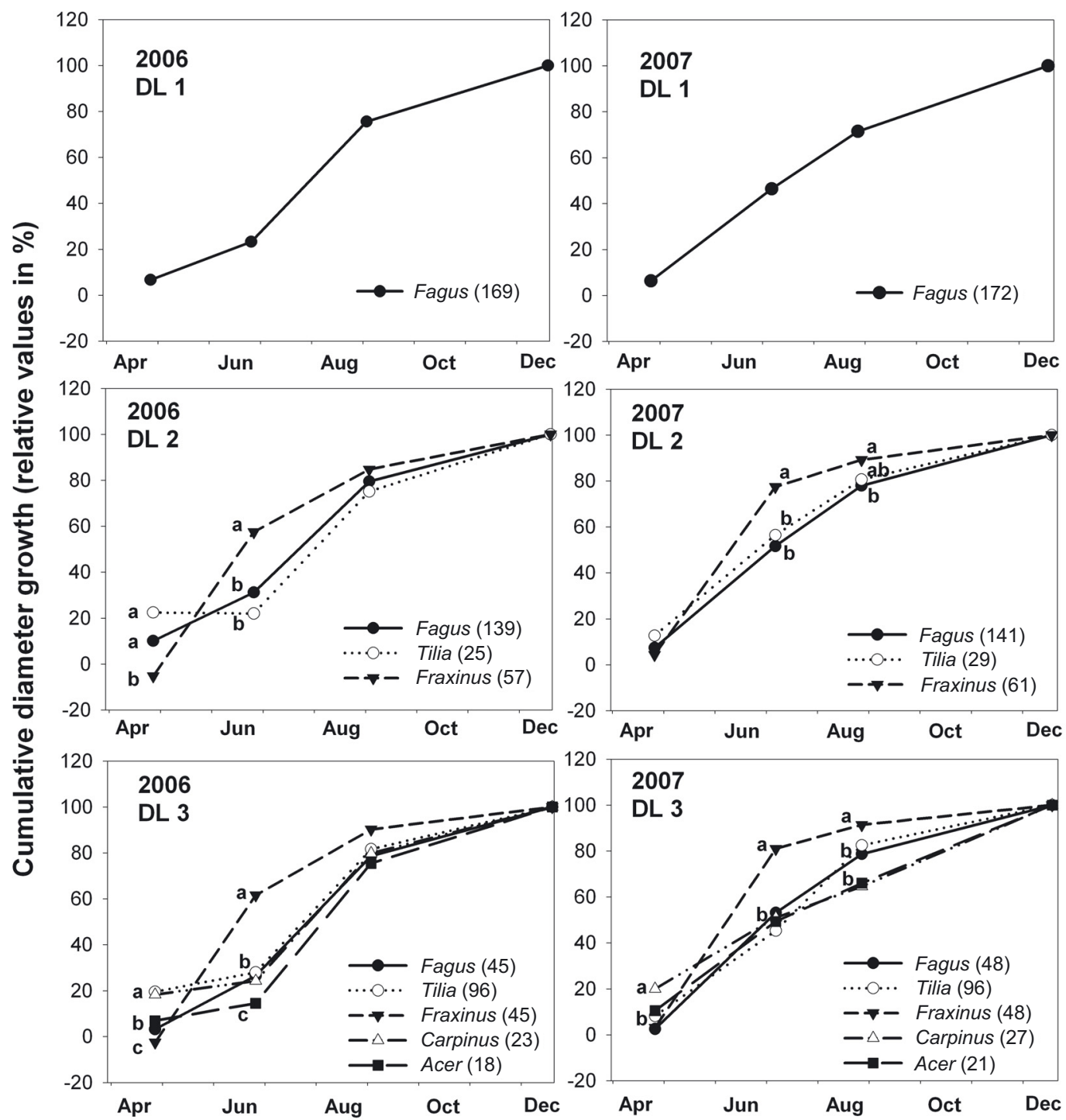

Figure 5. Relative cumulative seasonal diameter growth for the dominant species at the three diversity levels in 2006 and 2007 . Significant differences between species at a given diversity level are indicated with small Latin letters. The number of trees per diversity level is shown in brackets.

in early-successional Mediterranean-type forests in Northeastern Spain, Vilà et al. (2007) detected a significant increase of wood production with increasing tree species richness across a broad range of environmental conditions. Age-dependent growth patterns of juniper woodlands in Spain result from differences in the management system. Rozas et al. (2008) found that Juniper productivity did change abruptly with the transformations of the traditional management system. A livestock decrease, however, could also have led to higher plant species diversity. Most differences observed in above-ground productivity among forest stands differing in tree species richness could be attributed to species-specific traits or contrasting site conditions rather than to the number of tree species present (Kerr et al., 1992; Pretzsch, 2005; Sánchez-Gómez et al. 2008; Vilà et al., 2003).
The decline of wood productivity with increasing diversity of tree genera in our study is probably related to the observed decrease in total above-ground tree biomass. Similar results were obtained in a study conducted in a variety of unmanaged forest stands in the Czech Republic, Poland and Slovakia, which covered stands composed of one to eight tree species (Szwagrzyk and Gazda, 2007). That study revealed a negative (yet insignificant) trend of above-ground biomass with increasing tree species richness within a range of aboveground biomass (169-536 $\mathrm{Mg} \mathrm{ha}^{-1}$ ) that was similar to our study (200-480 $\left.\mathrm{Mg} \mathrm{ha}^{-1}\right)$. With regard to biomass accumulation by Fagus sylvatica, the results obtained in the study by Szwagrzyk and Gazda (2007) fit our findings well: the share of beech was positively correlated with biomass accumulation, and the highest above-ground biomass was found in pure 
stands of Fagus. However, in our study, this result cannot be explained by the "sampling effect", i.e. the effect that the most productive species of a given community determines the level of productivity (cf. Hooper et al., 2005). In our study, the trend towards a higher biomass in the pure beech stands could be due to the increased tree age of the canopy trees. However, multiple regression analysis revealed a higher influence of the tree diversity compared to stand age or the interaction of both factors. Furthermore, the higher biomass accumulation in beech stands cannot be attributed to a better nutrient supply: compared to the mixed species stands, the Fagus stands exhibited a significantly lower soil $\mathrm{pH}$ and base saturation, and tended towards a lower cation exchange capacity and higher $\mathrm{C}: \mathrm{N}$ ratios (Guckland et al., 2009), which is believed to be mainly a result of Fagus leaf and root litter effects on the soil.

In the investigated forest stands, the annual production of wood and leaves was similar to that of a highly diverse (eight predominating tree species) mesic temperate deciduous forest in the Southeast of North America (Newman et al., 2006). In contrast to Newman et al. (2006), the total production of wood and leaves in our study did not differ significantly in most cases, despite distinct differences in the weather conditions between the study years. The increase in the leaf area index (LAI) with increasing tree species diversity can be explained with a larger biomass investment into the leaves (compared to wood) in Tilia, Carpinus and Acer that, in addition, also display a high specific leaf area (SLA) (data on request).

Different tree species are capable of using the water and nutrient resources from the soil in a complementary manner due to differences in root architecture (cf. Köstler et al., 1968; Kutschera and Lichtenegger, 2002). In the present study, we did not find such positive effects of complementarity on the production and accumulation of biomass as there were no significant species differences in rooting patterns among the three diversity levels (Meinen et al., 2009). Complementarity could also be possible with regard to temporal differences in the use of below-ground or above-ground resources. In the mixed species forest stands of our study, Fraxinus had reached 60$80 \%$ of its annual increment in basal area already at the end of June, whereas the seasonal growth dynamics of Tilia seemed to be more dependent on the weather: growth of Tilia was slow in the cool and moist spring of 2006, but much faster in the warm spring of 2007. Fraxinus, the only ring-porous tree species of our study, leaves out later than the other tree species. Therefore, its early stem growth cannot be explained by higher photosynthesis rates but rather by the formation of early wood and of the main conducting vessels for water transport (Gebauer et al., 2008).

The growth of Fagus was slower than that of Fraxinus in the mixed forest stands. Most likely, rapid early stem growth of Fraxinus can be tolerated by Fagus because the slender crowns of Fraxinus, which can utilize even small gaps within a closed forest stand, only have a small shading effect on the surrounding trees. On the other hand, Fagus is competitively superior to other Central European deciduous forest tree species due to its higher shade tolerance in juvenile stages (Ellenberg, 1996), its low crown transmissivity of photosynthetically active radiation that causes severe shading of competing species
(Leuschner, 1998), and its capability of efficiently exploring the crown space by its foliage mass and its annual branch volume increment (Reiter et al., 2005). However, differential seasonal growth patterns among the species did not result in increased productivity at the plot level compared to the monospecific stands.

We summarize that above-ground productivity of the investigated mature temperate deciduous forest stands is remarkably constant not only for different levels of tree species diversity but also over subsequent years, if water availability is sufficient. Tilia, Acer and Carpinus invest a large fraction of carbon into the production of foliage and, thus, enhance carbon cycling in mixed species stands, whereas the production of stem wood in Fagus trees exceeds leaf production and results in longer carbon storage in monospecific stands. Our data suggest that above-ground net primary production is much more under the control of climate and edaphic factors than dependent on tree species diversity. Furthermore, characteristic physiological, morphological and architectural traits, which control productivity, seem to be more influential than the mere number of species present.

Acknowledgements: We thank the German Research Council (DFG) for funding the Research Training Group (Graduiertenkolleg) 1086. Many colleagues from the Research Training Group supported our studies with data and comments.

\section{REFERENCES}

Augusto L., Ranger J., Binkley D., and Rothe A., 2002. Impact of several common tree species of European temperate forests on soil fertility. Ann. For. Sci. 59: 233-253.

Bartelink H.H., 2000. Effects of stand composition and thinning in mixedspecies forests: a modeling approach applied to Douglas-fir and beech. Tree Physiol. 20: 399-406.

BMVEL, 2001. Gesamtwaldbericht der Bundesregierung. BMVEL (Bundesministerium für Verbraucherschutz, Ernährung und Landwirtschaft), Bonn, $141 \mathrm{p}$.

Bunce R.G.H., 1968. Biomass and production of trees in a mixed deciduous woodland: I. Girth and height as parameters for estimation of tree dry weight. J. Ecol. 56: 759-775.

Cannell M.G.R., Malcolm D.C., and Robertson P.A., 1992. The ecology of mixed-species stands of trees. Blackwell, Oxford, $312 \mathrm{p}$.

Ellenberg H., 1996. Vegetation Mitteleuropas mit den Alpen. Ulmer, Stuttgart, $981 \mathrm{p}$.

Enquist B.J. and Niklas K.J., 2001. Invariant scaling relations across treedominated communities. Nature 410: 655-660.

Fornara D.A. and Tilman D., 2008. Plant functional composition influences rates of soil carbon and nitrogen accumulation. J. Ecol. 9: 314322.

Gebauer T., Horna V., and Leuschner C., 2008. Variability in radial sap flux density patterns and sapwood area among seven co-occurring temperate broad-leaved tree species. Tree Physiol. 28: 1821-1830.

Guckland A., Jacob M., Flessa H., Thomas F.M., and Leuschner C., 2009. Acidity, nutrient stocks- and organic-matter content in soils of a temperate deciduous forest with different abundance of European beech (Fagus sylvatica L.). J. Plant Nutr. Soil Sci. 172: 500-511.

Hooper D.U., Chapin F.S., Ewel J.J., Hector A., Inchausti P., Lavorel S., Lawton J.H., Lodge D.M., Loreau M., Naeem S., Schmid B., Setälä H., Symstad A.J., Vandermeer J., and Wardle D.A., 2005. Effects of biodiversity on ecosystem functioning: A consensus of current knowledge. Ecol. Monogr. 75: 3-35. 
Hooper D.U. and Vitousek P.M., 1997. The effects of plant composition and diversity on ecosystem processes. Science 277: 1302-1305.

Kerr G., Nixon C.J., and Matthews R.W., 1992. Silviculture and yield of mixed-species stands: the UK experience. In: Cannell M.G.R., Malcolm D.C., Robertson P.A. (Eds.), The ecology of mixed-species stands of trees, Oxford, Blackwell Oxford, pp. 35-51.

Kraft G., 1884. Beiträge zur Lehre von den Durchforstungen, Schlagstellungen und Lichtungshieben. Klindworth's Verlag, Hannover.

Köstler J.N., Brückner E., and Bibelriether H., 1968. Die Wurzeln der Waldbäume. Parey, Hamburg, 284 p.

Kutschera L. and Lichtenegger E., 2002. Wurzelatlas mitteleuropäischer Waldbäume und Sträucher. Leopold Stocker Verlag, Graz, 604 p.

Leuschner C., 1998. Mechanismen der Konkurrenzüberlegenheit der Rotbuche. Berichte der Reinhold-Tüxen-Gesellschaft 10: 5-18.

Leuschner C., Jungkunst H., and Fleck S., 2009. Functional role of forest diversity: Pros and cons of synthetic stands and across-site comparisons in established forests. Basic Appl. Ecol. 10, 1-9.

Meinen C., Hertel D., and Leuschner C., 2009. Biomass and morphology of fine roots in temperate broad-leaved forests differing in tree species diversity: is there evidence of below-ground overyielding? Oecologia, 161: 99-11.

Newman G.S., Arthur M.A., and Muller R.N., 2006. Above- and belowground net primary production in a temperate mixed deciduous forest. Ecosystems 9: 317-329.

Pretzsch H., 2005. Diversity and productivity in forests: evidence from long-term experimental plots. In: Scherer-Lorenzen M., Körner Ch., Schulze E.D. (Eds.), Forest Diversity and Function - Temperate and Boreal Systems, Ecological Studies 176, Springer, Berlin, pp. 41-64.

Pretzsch H. and Schütze G., 2009. Transgressive overyielding in mixed compared with pure stands of Norway spruce and European beech in Central Europe: evidence on stand level and explanation on individual tree level. Eur. J. For. Res. 128: 183-204.

R Development Core Team, 2008. R: A language and environment for statistical computing. R Foundation for Statistical Computing, Vienna, Austria. URL http://www.R-project.org.

Reiter I.M., Häberle K.H., Nunn A.J., Heerdt C., Reitmayer H., Grote R., and Matyssek R., 2005. Competitive strategies in adult beech and spruce: space-related foliar carbon investment versus carbon gain. Oecologia 146: 337-349.

Rothe A. and Binkley D., 2001. Nutritional interactions in mixed species forests: a synthesis. Can. J. For. Res. 31: 1855-1870.

Rothe A., Kreutzer K., and Küchenhoff H., 2002. Influence of tree species composition on soil and soil solution properties in two mixed sprucebeech stands with contrasting history in Southern Germany. Plant Soil 240: 47-56.
Rozas V., Olano J.M., De Soto L., and Bartolomé D., 2008. Large-scale structural variation and long-term growth dynamics of Juniperus thurifera trees in a managed woodland in Soria, central Spain. Ann. For. Sci. 65: 809 .

Sánchez-Gómez D., Zavala M.A., Van Schalkwijk D.B., Urbieta I.R., and Valladares F., 2008. Rank reversals in tree growth along tree size, competition and climatic gradients for four forest canopy dominant species in Central Spain. Ann. For. Sci. 65: 605.

Scherer-Lorenzen M., Körner Ch., and Schulze E.D., 2005. The functional significance of forest diversity: a synthesis. In: SchererLorenzen M., Körner Ch., Schulze E.D. (Eds.), Forest Diversity and Function - Temperate and Boreal Systems, Ecological Studies 176, Springer, Berlin, pp. 377-389.

Schmidt I., Leuschner C., Mölder A., and Schmidt W., 2009. Structure and composition of the seed bank in monospecific and tree speciesrich temperate broad-leaved forests. For. Ecol. Manage. 257: 695702.

Spehn E.M., Hector A., Joshi J., Scherer-Lorenzen M., Schmid B., Bazeley-White E., Beierkuhnlein C., Caldeira M.C., Diemer M., Dimitrakopoulos P.G., Finn J.A., Freitas H., Giller P.S., Good J., Harris R., Högberg P., Huss-Danell K., Jumpponen A., Koricheva J., Leadley P.W., Loreau M., Minns A., Mulder C.P.H., O’Donovan G., Otway S.J., Palmborg C., Pereira J.S., Pfisterer A.B., Prinz A., Read D.J., Schulze E.D., Siamantziouras A.S.D., Terry A.C., Troumbis A.Y., Woodward F.I., Yachi S., and Lawton J.H., 2005. Ecosystem effects of biodiversity manipulations in European grasslands. Ecol. Monogr. 75: 37-63.

Szwagrzyk J. and Gazda A., 2007. Above-ground standing biomass and tree species diversity in natural stands of Central Europe. J. Veg. Sci. 18: $555-562$.

Vilà M., Vayreda J., Gracia C., and Ibáñez J.J., 2003. Does tree diversity increase wood production in pine forests? Oecologia 135: 299-303.

Vilà M., Vayreda J., Comas L., Ibáñez J.J., Mata T., and Obón B., 2007. Species richness and wood production: a positive association in Mediterranean forests. Ecol. Lett. 10: 241-250.

Wirth C., Schulze E.D., Schwalbe G., Tomczyk S., Weber G., and Weller E., 2004. Dynamik der Kohlenstoffvorräte in den Wäldern Thüringens. Thüringer Landesanstalt für Wald, Jagd und Fischerei, Gotha, 302 p.

Yachi S. and Loreau M., 2007. Does complementary resource use enhance ecosystem functioning? A model of light competition in plant communities. Ecol. Lett. 10: 54-62.

Zianis D., Muukkonen P., Mäkipää R., and Menuccini M., 2005. Biomass and stem volume equations for tree species in Europe. Silva Fenn. Monogr. 4, 63 p. 